\title{
Widespread distribution of CTX-M and plasmid-mediated AmpC $\beta$-lactamases in Escherichia coli from Brazilian chicken meat
}

\author{
Larissa Alvarenga Batista Botelho, Gabriela Bergiante Kraychete, \\ Jacqueline Lapa Costa e Silva, Douglas Viller Vieira Regis, \\ Renata Cristina Picão, Beatriz Meurer Moreira, Raquel Regina Bonelli/ ${ }^{+}$
}

Laboratório de Investigação em Microbiologia Médica, Instituto de Microbiologia Paulo de Góes, Universidade Federal do Rio de Janeiro, Rio de Janeiro, RJ, Brasil

\begin{abstract}
The dissemination of plasmid-mediated antimicrobial resistance genes may pose a substantial public health risk. In the present work, the occurrences of $\mathrm{bla}_{C T X-M}$ and plasmid-mediated $\mathrm{ampC}$ and $\mathrm{qnr}$ genes were investigated in Escherichia coli from 16 chicken carcasses produced by four commercial brands in Brazil. Of the brands tested, three were exporters, including one of organic chicken. Our study assessed $136 \mathrm{E}$. coli isolates that were grouped into 77 distinct biotypes defined by their origin, resistance profiling, the presence of $\beta$-lactamase and plasmid-mediated quinolone resistance genes and enterobacterial repetitive intergenic consensus-polimerase chain reaction typing. The bla ${ }_{C T X-M-15}$, $\mathrm{bla}_{C T X-M-2}$ and $\mathrm{bla}_{C T X-M-8}$ genes were detected in one, 17 and eight different biotypes, respectively (45 isolates). Twentyone biotypes (46 isolates) harboured $\mathrm{bla}_{C M Y-2}$. Additionally, $\mathrm{bla}_{C_{M Y-2}}$ was identified in isolates that also carried either $\mathrm{bla}_{C T X-M-2}$ or $\mathrm{bla}_{\text {CTX-M-8. }}$. The qnrB and/or qnrS genes occurred in isolates carrying each of the four types of $\beta$-lactamase determinants detected and also in oxyimino-cephalosporin-susceptible strains. Plasmid-mediated extended-spectrum $\beta$-lactamase (ESBL) and AmpC determinants were identified in carcasses from the four brands tested. Notably, this is the first description of $\mathrm{bla}_{C T X-M-15}$ genes in meat or food-producing animals from South America. The bla $\mathrm{b}_{C T X-M-\delta}, \mathrm{bla}_{\text {CTX- }}$ ${ }_{M-15}$ and $\mathrm{bla}_{C M Y-2}$ genes were transferable in conjugation experiments. The findings of the present study indicate that plasmid-mediated ESBL and AmpC-encoding genes are widely distributed in Brazilian chicken meat.
\end{abstract}

Key words: ESBL - plasmid AmpC - qnr - chicken meat - Escherichia coli

Extended-spectrum $\beta$-lactamase (ESBL)-producing Enterobacteriaceae are becoming increasingly prevalent in community-associated infections (Ben-Ami et al. 2009). A potential role for chicken meat as a source of multidrugresistant (MDR) bacteria carrying ESBL and plasmidmediated $\mathrm{AmpC}(\mathrm{pAmpC})$ determinants in the population has been demonstrated (Bergenholtz et al. 2009, Dhanji et al. 2010, Doi et al. 2010, Kola et al. 2012). Indeed, different studies have supported the hypothesis that bacterial pathogens, including resistant isolates, can be transmitted from chicken meat to humans (Thorsteinsdottir et al. 2010, Vincent et al. 2010, Overdevest et al. 2011).

Brazil is one of the world's most important producers and the leading exporter of chicken meat, with markets in different countries of Europe, Asia and the Middle East (USITC 2012). Despite this widespread distribution, most studies describing Escherichia coli isolates carrying CTX-M- and CMY-encoding genes in retail meat were performed with chicken produced in Europe and Asia (Ewers et al. 2012, Kola et al. 2012, Stuart et al. 2012,

doi: 10.1590/0074-02760140389

Financial support: CNPq, FAPERJ, CAPES

+Corresponding author: raquel.bonelli@micro.ufrj.br

Received 20 October 2014

Accepted 26 January 2015
$\mathrm{Xu}$ et al. 2014). Reports investigating the presence of $\beta$-lactamase determinants in E. coli from Brazilian chicken are scant and are concentrated on samples imported by Denmark and the United Kingdom (Warren et al. 2008, Bergenholtz et al. 2009, Dhanji et al. 2010). Moreover, the occurrence of bla $a_{\text {СTX-M-2 }}$ on the chromosome of $E$. coli isolates was recently demonstrated in chicken produced by two Brazilian farms (Ferreira et al. 2014).

In the present study, we presented evidence for the contamination of Brazilian chicken carcasses with CTX-M and pAmpC-producing E. coli. We investigated several brands, including exporters and regional and organic producers. E. coli isolates were categorised by antimicrobial resistance, the presence of $\beta$-lactamase and $q n r$ plasmid-mediated quinolone resistance genes and phylogenetic background. The conjugative transfer potentials of the $\beta$-lactamase genes were also determined.

\section{MATERIALS AND METHODS}

Sample collection - Between August 2010-April 2011, 16 frozen chicken carcasses were obtained from four Brazilian producers (I, II, III and IV, four carcasses each) at retail markets in Rio de Janeiro, Brazil. Producers I, II and III sell conventional chicken and brand I and II products are distributed in Brazil and internationally. Producer III distributes chicken only in Brazil; however, carcasses sold as "premium export grade" were selected for the study. Producer IV has the same commercial characteristics of I and II, but specialises in organic chicken. Whole frozen chicken carcasses in 
original packages were chosen as the sample source to avoid the risk of additional contamination after leaving the processing plant.

Recovery of E. coli isolates - Each carcass was left to defrost at $4-8^{\circ} \mathrm{C}$ for $36 \mathrm{~h}$ and subsequently rinsed with 300 $\mathrm{mL}$ of sterile buffered peptone water (Difco, EUA). Four $100-\mu \mathrm{L}$ aliquots of the obtained rinsate were directly inoculated onto MacConkey agar (Difco) plates, including one untreated plate and three plates each supplemented with one of the following antimicrobial agents: ampicillin $(8 \mathrm{mg} / \mathrm{L})$, cefotaxime $(2 \mathrm{mg} / \mathrm{L})$ or sulfamethoxazole $(500 \mathrm{mg} / \mathrm{L})$. Additional $300-\mu \mathrm{L}$ aliquots of the rinsate were pre-incubated in MacConkey broth without antimicrobial selection pressure in quadruplicate (Difco) in 1:10 dilutions for $4 \mathrm{~h}$. Four $100-\mu \mathrm{L}$ aliquots of each of the pre-incubated cultures were inoculated onto the agar plates without antimicrobials or with ampicillin $(8 \mathrm{mg} / \mathrm{L})$, cefotaxime $(2 \mathrm{mg} / \mathrm{L})$ or sulfamethoxazole $(500 \mathrm{mg} / \mathrm{L})$, totalling 16 additional plates. Up to five colonies were selected from each plate, with a priority on those exhibiting different morphological characteristics, for identification by classic phenotypic tests: lactose fermentation, Gram staining, indole production and 4-methylumbelliferyl- $\beta$ D-glucuronide hydrolysis. Isolates presumptively identified as $E$. coli were confirmed by MALDI-TOF MS (Bruker Biotyper 3.1, Bruker Daltonics). A single confirmed E. coli isolate per plate was included in this study and submitted for complete characterisation.

Antimicrobial susceptibility testing - Susceptibility was determined by the Clinical Laboratory Standard Institute (CLSI) disk-diffusion method for amoxicillin/clavulanate, ampicillin, aztreonam, cefotaxime, cefoxitin, cefuroxime, chloramphenicol, ciprofloxacin, ertapenem, fosfomycin/trometamol, gentamicin, nitrofurantoin, tetracycline and trimethoprim/sulfamethoxazone (CLSI 2014). Isolates were classified as MDR according to previously described criteria (Magiorakos et al. 2012).

Detection of CTX-M and pAmpC $\beta$-lactamases Screening for ESBL producers was conducted by doubledisk synergy testing using aztreonam $(30 \mu \mathrm{g})$, cefepime $(30 \mu \mathrm{g})$, cefotaxime $(30 \mu \mathrm{g})$ and ceftazidime $(30 \mu \mathrm{g})$ as substrates and amoxicillin/clavulanate $(20 / 10 \mu \mathrm{g})$ as an ESBL inhibitor (Jarlier et al. 1988). ESBL-producing $E$. coli isolates were subjected to polymerase chain reaction (PCR) for different bla $_{\text {Стх-м.- }}$ groups (Wang et al. 2012). Amplification parameters varied slightly according to the $b l a_{\text {CTX-M }}$ group analysed. For groups 1, 9 and 25, the following PCR conditions were applied: $94^{\circ} \mathrm{C}$ for $3 \mathrm{~min}$, 35 cycles of $94^{\circ} \mathrm{C}$ for $30 \mathrm{~s}, 51^{\circ} \mathrm{C}$ for $1 \mathrm{~min}$ and $72^{\circ} \mathrm{C}$ for 2 min with a final extension step of $72^{\circ} \mathrm{C}$ for $5 \mathrm{~min}$. Amplicons for groups 2 and 8 were obtained under the same conditions, except for the annealing temperature $\left(56^{\circ} \mathrm{C}\right)$.

Isolates resistant to cefoxitin and amoxicillin/clavulanate were submitted for confirmatory phenotypic testing for AmpC enzymes using cloxacillin $(200 \mu \mathrm{g})$ as an inhibitor (Tan et al. 2009, Peter-Getzlaff et al. 2011). Positive isolates were examined for the presence of genes encoding the pAmpC enzymes CMY, ACC, ACT, DHA, FOX, LAT, MIR and MOX by multiplex PCR as previously described (Pérez-Pérez \& Hanson 2002).
Amplicons were purified using ExoSAP-IT (USB Corporation, USA) and sequenced by Macrogen Inc (South Korea) to define the $b l a_{\mathrm{CTX}-\mathrm{M}}$ and ampC-type $\beta$-lactamase gene variants. The obtained sequences were compared to reference sequences available in GenBank (ncbi.nlm.nih.gov/).

Detection of qnr genes - All isolates were examined for $q n r A, q n r B$ and $q n r S$ genes by multiplex PCR as previously described (Cattoir et al. 2007).

Phylogenetic typing - The phylogenetic group from each $E$. coli isolate was determined by multiplex PCR for chuA and yjaA genes and the DNA fragment $\mathrm{TspE} 4 \mathrm{C} 2$, as described (Clermont et al. 2000).

Enterobacterial repetitive intergenic consensus (ERIC)2-PCR - All isolates were typed by ERIC2-PCR (Dias et al. 2008) and DNA fingerprints were assessed by visual inspection. Band profiles of representative biotypes (selected as described below) were additionally analysed by BioNumerics v.7.1 (Applied Maths, Belgium) with Dice similarity coefficients, an unweighted-pair group method using average linkages and a bandwidth tolerance of $1 \%$. Isolates with $100 \%$ similarity were included in a single genotype.

Definition of representative biotypes - From each carcass, one isolate of each biotype was selected as a representative strain. A biotype was defined for each unique combination of the following characteristics: antimicrobial resistance profile, carriage of the assessed $q n r$ and $\beta$-lactamase encoding genes, phylogenetic group and ERIC2-PCR type.

Conjugation experiments - To determine the presence of $\beta$-lactamase-encoding genes within conjugative plasmids, mating-out assays were performed for at least one $E$. coli isolate carrying each $\beta$-lactamase gene found. The sodium azide-resistant $E$. coli J53 strain was used as the recipient; transconjugants were selected in sodium azide $(100 \mathrm{mg} / \mathrm{L})$ and ceftriaxone $(2 \mathrm{mg} / \mathrm{L})$ containing plates. Gene transfer was confirmed by PCR with a transconjugant DNA template. Transconjugants were subjected to antimicrobial susceptibility tests for $\beta$-lactam and non- $\beta$-lactam agents by disk-diffusion. ERIC2-PCR typing was performed to distinguish transconjugants from donor strains.

\section{RESULTS}

Sample collection - A total of 689 colonies were cultured and $216(31 \%)$ were confirmed as E. coli. From these, a subset of 136 isolates was formed, comprising $63 \%$ of the 216 E. coli identified, by selecting one colony per agar plate. According to the criteria established and considering the results detailed below, these isolates were grouped into 77 representative biotypes.

Prevalence of MDR isolates - Overall, MDR E. coli from carcasses of brands I, II, II and IV comprised 23 out of $26(89 \%), 21$ out of $23(91 \%), 11$ out of $13(85 \%)$ and 12 out of $15(80 \%)$ biotypes analysed, respectively. As a consequence of the selective pressure applied, high resistance rates for $\beta$-lactam agents were observed. Resistance 
TABLE

Key characteristics of Escherichia coli biotypes showing oxyimino-cephalosporin resistance obtained from frozen chicken carcasses produced in Brazil

\begin{tabular}{|c|c|c|c|c|c|c|c|}
\hline $\begin{array}{l}\beta \text {-lactamase } \\
\text { gene }\end{array}$ & $\begin{array}{c}\beta \text {-lactam resistance } \\
\text { profile }\end{array}$ & $\begin{array}{l}\text { Additional } \\
\text { resistance }\end{array}$ & $\begin{array}{l}\text { Phylogenetic } \\
\text { group }\end{array}$ & $\begin{array}{l}q n r \\
\text { gene }\end{array}$ & $\begin{array}{c}\text { Carcass } \\
\text { (brand/unit) }^{a}\end{array}$ & $\begin{array}{l}\text { Selective pressure used } \\
\text { (number of isolates) }\end{array}$ & $\begin{array}{l}\text { Biotype } \\
\text { number }^{b}\end{array}$ \\
\hline \multirow[t]{16}{*}{$b l a_{\mathrm{CTX}-\mathrm{M}-2}$} & AMP-CTX-CXM & CLO & $\mathrm{D}$ & - & I. 2 & None (1), AMP (1) & 3 \\
\hline & AMP-CTX-CXM & CLO-FOS & $\mathrm{D}$ & - & I. 2 & $\begin{array}{l}\text { None (1), AMP (2), } \\
\text { CTX (2), SUL (1) }\end{array}$ & 4 \\
\hline & AMP-CTX-CXM & CIP-GEN & $\mathrm{A}$ & - & I.1 & AMP (1) & $1^{c}$ \\
\hline & AMP-CTX-CXM & CIP-GEN & A & - & I.1 & CTX (1), SUL (1) & $2^{c}$ \\
\hline & AMP-CTX-CXM & CIP-TET & B1 & - & II. 3 & SUL (1) & 25 \\
\hline & AMP-CTX-CXM & $\begin{array}{l}\text { CIP-GEN- } \\
\text { SXT }\end{array}$ & A & - & II. 2 & CTX (1) & 18 \\
\hline & AMP-CTX-CXM & $\begin{array}{l}\text { CIP-GEN- } \\
\text { SXT-TET }\end{array}$ & A & - & II. 2 & AMP (1) & 19 \\
\hline & AMP-ATM-CTX-CXM & CIP & $\mathrm{D}$ & $q n r B$ & IV.4 & SUL (1) & 44 \\
\hline & AMP-ATM-CTX-CXM & CLO & $\mathrm{D}$ & - & I. 2 & CTX (1), SUL (1) & $5^{c}$ \\
\hline & AMP-ATM-CTX-CXM & CLO & $\mathrm{D}$ & - & I. 2 & SUL (1) & $6^{c}$ \\
\hline & AMP-ATM-CTX-CXM & TET & B1 & - & I. 3 & $\begin{array}{c}\text { None (1), AMP (2), } \\
\text { SUL (2) }\end{array}$ & 7 \\
\hline & AMP-ATM-CTX-CXM & CIP-TET & B1 & - & II.1 & CTX (1), SUL (1) & 16 \\
\hline & AMP-ATM-CTX-CXM & GEN-TET & B1 & - & I. 3 & CTX (1) & 8 \\
\hline & AMP-ATM-CTX-CXM & $\begin{array}{l}\text { CIP-GEN- } \\
\text { SXT-TET }\end{array}$ & $\mathrm{D}$ & - & II. 2 & SUL (1) & 20 \\
\hline & AMP-ATM-CTX-CXM & $\begin{array}{c}\text { CIP-FOS- } \\
\text { GEN-SXT-TET }\end{array}$ & B1 & - & II. 2 & CTX (1) & 21 \\
\hline & AMC-AMP-ATM-CTX-CXM & CIP-CLO & $\mathrm{D}$ & - & IV.2 & $\begin{array}{c}\text { AMP (1), CTX (1), } \\
\text { SUL (1) }\end{array}$ & 38 \\
\hline \multirow{7}{*}{$b l a_{\text {СТХ-М-8 }}$} & AMP-CTX-CXM & - & B1 & $q n r B$ & I. 3 & None (1) & 9 \\
\hline & AMP-CTX-CXM & - & $\mathrm{D}$ & - & I. 3 & CTX (1) & 10 \\
\hline & AMP-CTX-CXM & - & $\mathrm{D}$ & - & III.4 & CTX (1) & 34 \\
\hline & AMP-CTX-CXM & CIP-TET & B1 & - & III.2 & CTX (1) & 31 \\
\hline & AMP-CTX-CXM & CIP-TET & B1 & - & III.4 & SUL (1) & 35 \\
\hline & AMP-ATM-CTX-CXM & - & B1 & - & III.1 & CTX (1) & 29 \\
\hline & AMP-ATM-CTX-CXM & - & B1 & - & IV.1 & $\begin{array}{c}\text { None (1), AMP (1), } \\
\text { CTX (1) }\end{array}$ & 36 \\
\hline$b l a_{\text {СТХ-м-15 }}$ & AMP-ATM-CTX-CXM & CIP-SXT-TET & B1 & $q n r S$ & IV.3 & $\begin{array}{c}\text { None (1), AMP (1), } \\
\text { CTX (1) }\end{array}$ & 41 \\
\hline \multirow{17}{*}{$\begin{array}{l}b l a_{\mathrm{CTX}-\mathrm{M}-2} / b l a_{\mathrm{CMY}-2} \\
b l a_{\text {СTX-M-8 }} / b l a_{\mathrm{CMY}-2} \\
b l a_{\mathrm{CMY}-2}\end{array}$} & AMC-AMP-ATM-CTX-CXM-FOX & FOS-SXT-TET & $\mathrm{D}$ & - & IV.2 & CTX (1) & 39 \\
\hline & AMC-AMP-CTX-CXM-FOX & - & A & - & IV.2 & None (1) & 40 \\
\hline & AMC-AMP-CTX-CXM-FOX & CLO & $\mathrm{D}$ & - & I.3 & SUL (1) & 11 \\
\hline & AMC-AMP-CTX-CXM-FOX & SXT & $\mathrm{D}$ & - & I. 3 & $\operatorname{AMP}(1)$ & 12 \\
\hline & AMC-AMP-CTX-CXM-FOX & TET & B1 & - & III.2 & SUL (1) & 32 \\
\hline & AMC-AMP-CTX-CXM-FOX & TET & $\mathrm{D}$ & - & III.1 & CTX (1) & 30 \\
\hline & AMC-AMP-CTX-CXM-FOX & CIP-CLO & $\mathrm{D}$ & - & I. 3 & CTX (1) & 13 \\
\hline & AMC-AMP-CTX-CXM-FOX & CIP-SXT & $\mathrm{D}$ & - & II. 2 & $\operatorname{AMP}(1)$ & $22^{c}$ \\
\hline & AMC-AMP-CTX-CXM-FOX & CIP-SXT & $\mathrm{D}$ & - & II. 2 & SUL (1) & $23^{c}$ \\
\hline & AMC-AMP-CTX-CXM-FOX & CIP-SXT & $\mathrm{D}$ & - & II. 4 & $\operatorname{AMP}(1)$, CTX (1) & 27 \\
\hline & AMC-AMP-CTX-CXM-FOX & CIP-TET & B1 & - & II. 3 & CTX (1) & 26 \\
\hline & AMC-AMP-CTX-CXM-FOX & CIP-TET & $\mathrm{D}$ & - & II. 4 & CTX (1) & 28 \\
\hline & AMC-AMP-CTX-CXM-FOX & CIP-TET & $\mathrm{D}$ & $q n r B$ & IV.3 & None (1) & 42 \\
\hline & AMC-AMP-CTX-CXM-FOX & GEN-SXT & $\mathrm{D}$ & - & I. 4 & $\begin{array}{l}\text { None (3), AMP (1), } \\
\text { CTX (4), SUL (3) }\end{array}$ & 14 \\
\hline & AMC-AMP-CTX-CXM-FOX & SXT-TET & $\mathrm{D}$ & - & II.1 & AMP (1) & 17 \\
\hline & AMC-AMP-CTX-CXM-FOX & GEN-SXT-TET & $\mathrm{D}$ & - & II. 2 & AMP (1) & 24 \\
\hline & AMC-AMP-CTX-CXM-FOX & $\begin{array}{l}\text { CLO-GEN- } \\
\text { SXT-TET }\end{array}$ & $\mathrm{D}$ & - & I.4 & AMP (1) & 15 \\
\hline
\end{tabular}




\begin{tabular}{|c|c|c|c|c|c|c|c|}
\hline $\begin{array}{l}\beta \text {-lactamase } \\
\text { gene }\end{array}$ & $\begin{array}{c}\beta \text {-lactam resistance } \\
\text { profile }\end{array}$ & $\begin{array}{l}\text { Additional } \\
\text { resistance }\end{array}$ & $\begin{array}{l}\text { Phylogenetic } \\
\text { group }\end{array}$ & $\begin{array}{l}q n r \\
\text { gene }\end{array}$ & $\begin{array}{c}\text { Carcass } \\
\text { (brand/unit) }^{a}\end{array}$ & $\begin{array}{l}\text { Selective pressure used } \\
\text { (number of isolates) }\end{array}$ & $\begin{array}{l}\text { Biotype } \\
\text { number }^{b}\end{array}$ \\
\hline & AMC-AMP-ATM-CTX-CXM-FOX & - & B1 & - & IV.3 & $\operatorname{CTX}(1)$ & 43 \\
\hline & AMC-AMP-ATM-CTX-CXM-FOX & - & $\mathrm{D}$ & - & IV.1 & $\begin{array}{c}\text { None (1), AMP (1), } \\
\text { CTX (1) }\end{array}$ & 37 \\
\hline & AMC-AMP-ATM-CTX-CXM-FOX & FOS & B1 & - & III.2 & CTX (1) & 33 \\
\hline & AMC-AMP-ATM-CTX-CXM-FOX & CIP-SXT-TET & $\mathrm{D}$ & - & IV.4 & $\begin{array}{l}\text { None (2), AMP (4), } \\
\text { CTX (4), SUL (3) }\end{array}$ & 45 \\
\hline
\end{tabular}

$a$ : brands I and II, conventional production system and exporters, brand III, conventional production system and local distribution, brand IV, organic production system and exporter; $b$ : biotype number was arbitrarily determined according to brand and number of carcass to strains with a unique combination of the characteristics [antimicrobial resistance profile, carriage of $q n r$ and $\beta$-lactamase encoding genes, phylogenetic group and enterobacterial repetitive intergenic consensus-polymerase chain reaction (ERIC2-PCR) type]; $c$ : biotypes differentiated only by ERIC2-PCR typing; AMC: amoxycillin/clavulanate; AMP: ampicillin; ATM: aztreonam; CIP: ciprofloxacin; CLO: chloramphenicol; CTX: cefotaxime; CXM: cefuroxime; FOS: fosfomycin/trometamol; FOX: cefoxitin; GEN: gentamicin; SUL: sulfamethoxazole; SXT: trimethoprim/SUL; TET: tetracycline.

to ampicillin, cefuroxime and cefotaxime occurred in 58 (75\%), $72(94 \%)$ and $45(58 \%)$ of the 77 biotypes, respectively. Cefoxitin and amoxicillin/clavulanate co-resistance was observed in 21 biotypes (27\%). Regarding non$\beta$-lactam agents, resistance to tetracycline, ciprofloxacin, trimethoprim/sulfamethoxazone, chloramphenicol and gentamicin was found in 37 (48\%), 35 (45\%), 31 (40\%), $18(23 \%)$ and $16(21 \%)$ biotypes, respectively. No isolates showed resistance to nitrofurantoin or ertapenem.

Occurrence of CTX-M and pAmpC-encoding genes - Overall, the 45 biotypes containing oxyimino-cephalosporin-resistant isolates showed at least one of the $\beta$-lactamase determinants investigated. Interestingly, 11 (24\%) of these 45 biotypes included isolates obtained from untreated MacConkey plates. Table summarises the results obtained with these strains. Twenty-six biotypes (34\%) showed positive ESBL phenotypes after doubledisk synergy tests. Further characterisation by PCR and sequencing showed 17 bla $a_{\text {СтХ-М-2 }}$, eight $b l a_{\text {СтХ-м-8 }}$ and one bla $a_{\mathrm{CTX}-\mathrm{M}-15}$-carrying biotypes. All isolates included in the 21 biotypes showing cefoxitin and amoxicillin/clavulanate resistance had a phenotype suggestive of AmpC production and harboured the bla $a_{\mathrm{CMY}-2}$ gene. Two isolates were also concomitant carriers of bla $_{\text {СтХ-M }}$-type genes (Table).

Occurrence of qnr genes - The qnr genes occurred more frequently among the 32 oxyimino-cephalosporinsusceptible biotypes $(n=9,28 \%)$ than among the 45 resistant $(\mathrm{n}=4,9 \%)$ biotypes $(\mathrm{p} \leq 0.05)$. Considering the oxyimino-cephalosporin-susceptible biotypes, one carried the $q n r S$ gene and eight carried the $q n r B$ gene. Four biotypes concomitantly harboured $q n r$ and $\beta$-lactamase genes with the following combinations: bla $a_{\mathrm{CTX-M-2}}$ and $q n r B, b l a_{\text {СтХ-М-8 }}$ and $q n r B, b l a_{\mathrm{CTX-M-15}}$ and $q n r S$ and $b l a_{\mathrm{C}-}$ MY-2 and $q n r B$ (Table).

Phylogenetic background - Regarding the phylogenetic background, no isolate among the $b l a_{\mathrm{CTX}-\mathrm{M}}$ or $b l a_{\mathrm{CMY}-}$ ${ }_{2}$-positive $E$. coli belonged to group B2. Biotypes harbouring bla ${ }_{\text {СТХ-М-2 }}$ were homogeneously distributed among the other three phylogenetic groups (4 biotypes in A, 5 in B1 and 8 in D), but group B1 was the most frequent among

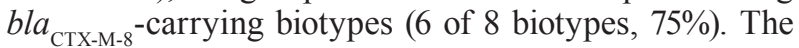
bla ${ }_{\mathrm{CMY}-2}$-carrying biotypes were associated with phylogenetic group $\mathrm{D}$ (16 of 21 biotypes, $76 \%, \mathrm{p} \leq 0.05$ ).

ERIC2-PCR typing - ERIC2-PCR typing was performed to confirm biotype classification and to ensure that no duplicate isolates were included in the study. A dendrogram from the computer-assisted analysis of the bla-carrying biotypes is shown in Figure. A great diversity of types was observed, except for two groups, which contained four and two biotypes that exhibited the same ERIC2-PCR types, but differed in their non- $\beta$-lactam antimicrobial resistance profiles.

Genes bla ${ }_{C T X-M-15}$, bla ${ }_{C T X-M-8}$ and bla ${ }_{C M Y-2}$, but not bla $_{C T X-M-2}$ were transferred by conjugation - Conjugation transfer was successfully performed for the bla $a_{\text {CTX-M-15, }}$, bla $a_{\mathrm{CTX}-\mathrm{M}-8}$ and $b l a_{\mathrm{CMY}-2}$ genes. For these experiments, six isolates from brand IV were selected as donor strains, each carrying genes encoding CTX-M-15, CTX-M-8, CTX-M-2 or CMY-2 enzymes only or CTX-M-8 plus CMY2 or CTX-M-2- plus CMY-2. Four transconjugant colonies were obtained for $b l a_{\text {CTX-M-15 }}$, all with the $q n r S$ gene co-transferred. Conjugation was also possible with the singular isolates carrying $b l a_{\text {СТХ-М-8 }}$ or $b l a_{\mathrm{CMY}-2}$. For the isolate harbouring the bla ${ }_{\text {СТХ-M-8 }}$ and bla $a_{\mathrm{CMY}-2}$ genes, five transconjugants were obtained: one with $b l a_{\text {CTX-M-8 }}$ only, two with bla $a_{\mathrm{CMY}-2}$ only and two with both genes. For the isolate carrying the bla $a_{\mathrm{CTX}-\mathrm{M}-2}$ and $b l a_{\mathrm{CMY}-2}$ genes, five transconjugants with bla $a_{\mathrm{CMY}-2}$ only were obtained. The antimicrobial susceptibility profile of transconjugants confirmed the transference and expression of the respective $\beta$-lactamase according to the preferential substrates of these enzymes. Because the $b l a_{\mathrm{CTX}-\mathrm{M}-2}$ gene transfer was unsuccessful with isolates from brand IV, conjugation experiments were performed with four additional isolates, two each from brands I and II, carrying only this gene. However, bla $a_{\text {СтХ-м-2 }}$ transference was not achieved. 


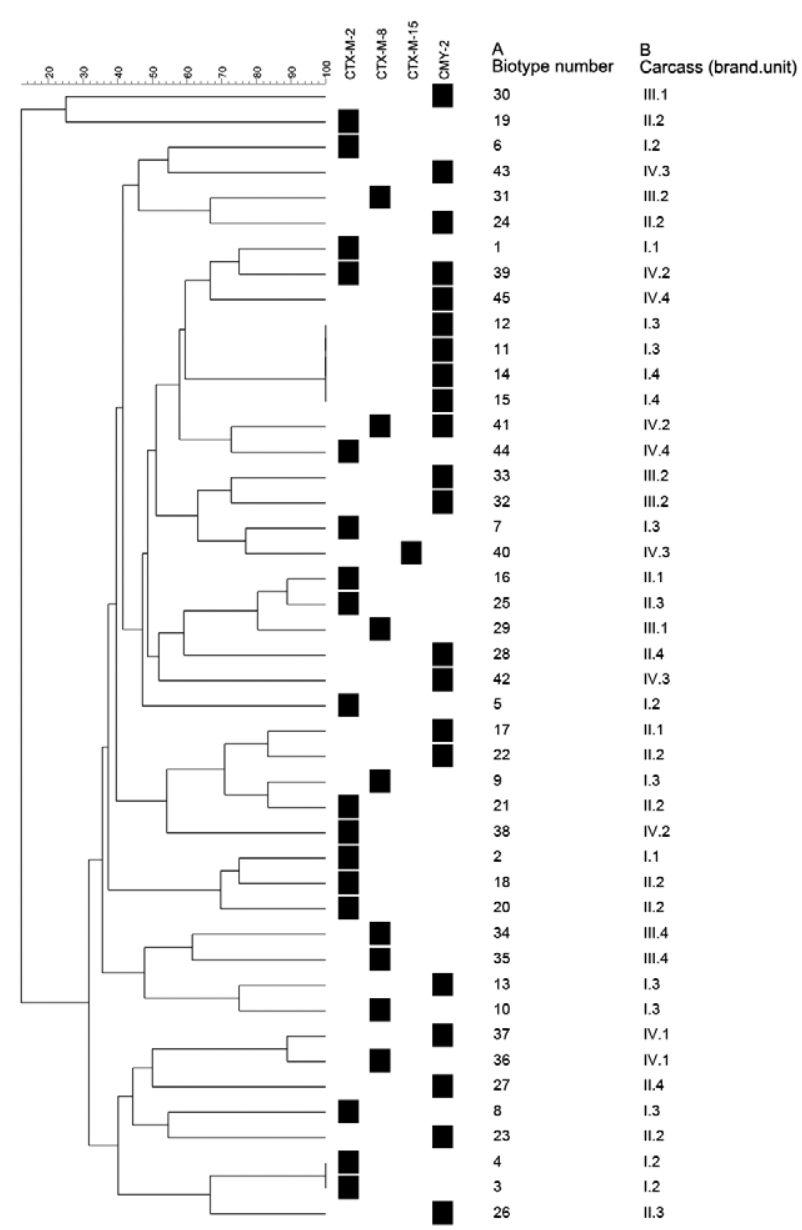

Distribution of 45 bla $a_{\text {СТХ-M }}$ and bla $a_{\text {СMY-2 }}$-carrying biotypes according to enterobacterial repetitive intergenic consensus-polymerase chain reaction (ERIC2-PCR) typing. A: biotype number was arbitrarily determined according to brand and number of carcass to strains with a unique combination of the following characteristics: antimicrobial resistance profile, carriage of $q n r$ and $\beta$-lactamase encoding genes, phylogenetic group and ERIC2-PCR type; B: brands I and II, conventional production system and exporters, brand III, conventional production system and local distribution, brand IV, organic production system and exporter.

\section{DISCUSSION}

Data obtained in this study demonstrated a wide distribution of $\beta$-lactamase-producing- $E$. coli in chicken meat produced in Brazil. The recovery of ESBL or plasmid AmpC-producing E. coli even in the absence of antimicrobial selection suggests that these isolates might be substantially represented among the microbiota from Brazilian chicken carcasses. Moreover, a high diversity of antimicrobial resistance phenotypes was observed among genetically diverse isolates, suggesting that conditions promoting resistance are well established.

The presence of MDR E. coli-carrying bla ${ }_{\text {CTX-M-2 }}$, $b l a_{\mathrm{CTX}-\mathrm{M}-8}$ and/or $b l a_{\mathrm{CMY}-2}$ in chicken meat produced in Brazil has been recently reported (Dhanji et al. 2010, Egervärn et al. 2014, Ferreira et al. 2014); nevertheless, the present paper is the first to describe $b l a_{\text {CTX-M-15 }}$ in $E$. coli from food or food-producing animals in South America.
Interestingly, organic chicken carcasses evaluated in our study showed the greatest diversity of bla genes (brand IV in Table). The single isolate presenting $b_{\text {CTX-M-15 }}$ and the two isolates simultaneously harbouring $b l a_{\text {CTX-M-type }}$ and $b l a_{\mathrm{CMY}_{-2}}$ were from this brand. Organic chicken meat contaminated with ESBL-producing bacteria has also been described in Germany and The Netherlands (Kola et al. 2012, Stuart et al. 2012). Possible sources of resistance genes in this setting are the introduction of one-day-old chicken already colonised with ESBL-producing organisms and the presence of such strains in the environment, as observed in fattening farms in Europe (MARAN 2009, Laube et al. 2013). In fact, considering the historical use of antimicrobials in commercial chicken production, the high rates of resistance observed in Enterobacteriaceae clinical isolates in this country and the existence of these genes in the environment, it is likely that these two possible sources exist in organic farms in Brazil (MAPA 2009, Gales et al. 2012, Picão et al. 2013).

Isolates carrying $b l a_{\mathrm{CTX}-\mathrm{M}-2}$ or $b l a_{\mathrm{CMY}-2}$ genes tended to accumulate resistance to a greater number of non- $\beta$ lactam antimicrobials (up to 5 or 4 , respectively) than did those carrying $b l a_{\text {CTX-M-8 }}$ genes (maximum 2). This tendency was independent of brand or phylogenetic group, suggesting that this multidrug-resistance phenotype is related to the genetic environment of these determinants, which will be investigated further.

The presence of ESBL and pAmpC-encoding genes in less pathogenic phylogenetic lineages could imply that they pose a minor risk to human health. However, in the present study, $\beta$-lactamase genes $b l a_{\mathrm{CMY}-2}, b l a_{\mathrm{CTX}-\mathrm{M}-8}$ and $b l a_{\text {CTX-M-15 }}$ of $E$. coli belonging to phylogenetic groups A and $\mathrm{D}, \mathrm{A}$ and $\mathrm{B} 1$ and $\mathrm{B} 1$, respectively, were easily transferred in vitro. This indicates that conjugation in the human gut with the transfer of $b l a_{\text {СТХ-м }}$ or $b l a_{\text {СMY-2 }}$ genes to more pathogenic B2 strains can occur, enabling the establishment of bacterial reservoirs of resistance genes in the human population.

In contrast to other $\beta$-lactamase genes, the transference of bla $a_{\text {CTX-M-2 }}$ was not achieved, even when testing isolates from brands with different production systems and commercial profiles. These results are in accordance with a study performed with $E$. coli obtained from two Brazilian farms (Ferreira et al. 2014) and suggest that the chromosomal location of bla $a_{\text {CTX-M-2 }}$ may be shared among many isolates from Brazilian chicken meat. However, further experiments are needed to confirm the genetics of this resistance determinant in our collection as well as the replicon typing of described self-transmissible plasmids carrying $b l a_{\text {CTX-M-8 }}, b l a_{\text {CTX-M-15 }}$ and $b l a_{\text {CMY-2. }}$.

The small number of chicken carcasses analysed is a limitation of this study. However, even with this small study sample, a great diversity of $E$. coli isolates carrying $b l a_{\mathrm{CTX}-\mathrm{M}-}$ types and $b l a_{\mathrm{CMY}-2}$ genes and showing a variety of resistance profiles to non- $\beta$-lactam antimicrobials was detected. The distribution of these microorganisms in different brands, phylogenetic groups and ERIC types supports their non-clonal nature and raises concerns about the high frequency of these antimicrobial resistance determinants in the Brazilian and international food chains. 


\section{REFERENCES}

Ben-Ami R, Rodríguez-Baño J, Arslan H, Pitout JD, Quentin C, Calbo ES, Azap OK, Arpin C, Pascual A, Livermore DM, Garau J, Carmeli Y 2009. A multinational survey of risk factors for infection with extended-spectrum beta-lactamase-producing Enterobacteriaceae in non-hospitalized patients. Clin Infect Dis 49: 682-690.

Bergenholtz RD, Jorgensen MS, Hansen LH, Jensen LB, Hasman H 2009. Characterization of genetic determinants of extended-spectrum cephalosporinases (ESCs) in Escherichia coli isolates from Danish and imported poultry meat. J Antimicrob Chemother 64: 207-209.

Cattoir V, Poirel L, Rotimi V, Soussy CJ, Nordmann P 2007. Multiplex PCR for detection of plasmid-mediated quinolone resistance $q n r$ genes in ESBL-producing enterobacterial isolates. $J$ Antimicrob Chemother 60: 394-397.

Clermont O, Bonacorsi S, Bingen E 2000. Rapid and simple determination of the Escherichia coli phylogenetic group. Appl Environ Microbiol 66: 4555-4558.

CLSI - Clinical and Laboratory Standards Institute 2014. Performance standards for antimicrobial susceptibility testing: twenty-fourth informational supplement, M100-S24, CLSI, Wayne, 230 pp.

Dhanji H, Murphy NM, Doumith M, Durmus S, Lee SS, Hope R, Woodford N, Livermore DM 2010. Cephalosporin resistance mechanisms in Escherichia coli isolated from raw chicken imported into the UK. $J$ Antimicrob Chemother 65: 2534-2537.

Dias RCS, Borges-Neto AA, Ferraiouli GID, de Oliveira MP, Riley LW, Moreira BM 2008. Prevalence of AmpC and other $\beta$-lactamases in enterobacteria at a large urban university hospital in Brazil. Diagn Microbiol Infect Dis 60: 79-87.

Doi Y, Paterson DL, Egea P, Pascual A, López-Cerero L, Navarro MD, Adams-Haduch JM, Qureshi ZA, Sidjabad HE, Rodríguez-Baño J 2010. Extended-spectrum and CMY-type $\beta$-lactamase-producing Escherichia coli in clinical samples and retail meat from Pittsburgh, USA and Seville, Spain. Clin Microbiol Infect 16: 33-38.

Egervärn M, Börjesson S, Byfors S, Finn M, Kaipe C, Englund S, Lindblad M 2014. Escherichia coli with extended-spectrum betalactamases or transferable AmpC beta-lactamases and Salmonella on meat imported into Sweden. Int J Food Microbiol 171: 8-14.

Ewers C, Bethe A, Semmler T, Guenther S, Wieler LH 2012. Extended-spectrum $\beta$-lactamase-producing and AmpC-producing Escherichia coli from livestock and companion animals and their putative impact on public health: a global perspective. Clin Microbiol Infect 18: 646-655.

Ferreira JC, Penha Filho RA, Andrade LN, Berchieri AJ, Darini ALC 2014. Detection of chromosomal bla СTХ-M-2 $_{\text {in }}$ diverse Escherichia coli isolates from healthy broiler chickens. Clin Microbiol Infect 20: 623-626.

Gales AC, Castanheira M, Jones RN, Sader HS 2012. Antimicrobial resistance among Gram-negative bacilli isolated from Latin America: results from SENTRY Antimicrobial Surveillance Program (Latin America, 2008-2010). Diagn Microbiol Infect Dis 73: 354-360.

Jarlier V, Nicolas MH, Fournier G, Philippon A 1988. Extended broadspectrum beta-lactamases conferring transferable resistance to newer beta-lactam agents in Enterobacteriaceae: hospital prevalence and susceptibility patterns. Rev Infect Dis 10: 867-878.

Kola A, Kohle C, Pfeifer Y, Schwab F, Kühn K, Schulz K, Balau V, Breitbach K, Bast A, Witte W, Gastmeier P, Steinmetz I 2012. High prevalence of extended-spectrum- $\beta$-lactamase-producing Enterobacteriaceae in organic and conventional retail chicken meat, Germany. J Antimicrob Chemother 67: 2631-2634.

Laube H, Friese A, von Salviati C, Guerra B, Käsbohrer A, Kreienbrock L, Roesler U 2013. Longitudinal monitoring of extended-spectrumbeta-lactamase/AmpC-producing Escherichia coli at German broiler chicken fattening farms. Appl Environ Microbiol 79: 4815-4820.
Magiorakos AP, Srinivasan A, Carey RB, Carmeli Y, Falagas ME, Giske CG, Harbarth S, Hindler JF, Kahlmeter G, Olsson-Liljequist B, Paterson DL, Rice LB, Stelling J, Struelens MJ, Vatopoulos A, Weber JT, Monnet DL 2012. Multidrug-resistant, extensively drug-resistant and pandrug-resistant bacteria: an international expert proposal for interim standard definitions for acquired resistance. Clin Microbiol Infect 18: 268-281.

MAPA - Ministério da Agricultura, Pecuária e Abastecimento Brasil 2009. Instrução normativa 26. Available from: extranet.agricultura.gov.br/sislegis-consulta.

MARAN - Monitoring of antimicrobial resistance and antibiotic usage in animals in The Netherlands in 2009. Available from: wageningenur.nl/upload_mm/d/7/a/cd29a66b-aaeb-4ba2-9284ce21ff6acc6d_MARAN2009.pdf.

Overdevest I, Willemsen I, Rijnsburger M, Eustace A, Xu L, Hawkey P, Heck M, Savelkoul P, Vandenbroucke-Grauls C, van der Zwaluw K, Huijsdens X, Kluytmans J 2011. Extended-spectrum $\beta$-lactamase genes of Escherichia coli in chicken meat and humans, The Netherlands. Emerg Infect Dis 17: 1216-1222.

Pérez-Pérez FJ, Hanson ND 2002. Detection of plasmid-mediated AmpC beta-lactamase genes in clinical isolates by using multiplex PCR. J Clin Microbiol 40: 2153-2162.

Peter-Getzlaff S, Polsfuss S, Poledica M, Hombach M, Giger J, Böttger EC, Zbinden R, Bloemberg GV 2011. Detection of AmpC beta-lactamase in Escherichia coli: comparison of three phenotypic confirmation assays and genetic analysis. J Clin Microbiol 49: 2924-2932.

Picão RC, Cardoso JP, Campana EH, Nicoletti AG, Petrolini FV, Assis DM, Juliano L, Gales AC 2013. The route of antimicrobial resistance from the hospital effluent to the environment: focus on the occurrence of KPC-producing Aeromonas spp and Enterobacteriaceae in sewage. Diagn Microbiol Infect Dis 76: 80-85.

Stuart JC, van den Munckhof T, Voets G, Scharringa J, Fluit A, Hall ML-V 2012. Comparison of ESBL contamination in organic and conventional retail chicken meat. Int J Food Microbiol 154: 212-214.

Tan TY, Ng LS, He J, Koh TH, Hsu LY 2009. Evaluation of screening methods to detect plasmid-mediated AmpC in Escherichia coli, Klebsiella pneumoniae and Proteus mirabilis. Antimicrob Agents Chemother 53: 146-149.

Thorsteinsdottir TR, Haraldsson G, Fridriksdottir V, Kristinsson KG, Gunnarsson E 2010. Broiler chickens as source of human fluoroquinolone-resistant Escherichia coli, Iceland. Emerg Infect Dis 16: 133-135.

USITC - United States International Trade Commission 2012. Brazil: competitive factors in Brazil affecting US and Brazilian agricultural sales in selected third country markets. Investigation 332524. Available from: usitc.gov/publications/332/pub4310.pdf.

Vincent C, Boerlin P, Daignault D, Dozois CM, Dutil L, Galanakis C, Reid-Smith RJ, Tellier PP, Tellis PA, Ziebell K, Manges AR 2010. Food reservoir for Escherichia coli causing urinary tract infections. Emerg Infect Dis 16: 88-95.

Wang X, Chen J, Kang Y, Jiang N, An S, Gao Z 2012. Prevalence and characterization of plasmid-mediated $b l a_{\mathrm{ESBL}}$ with their genetic environment in Escherichia coli and Klebsiella pneumoniae in patients with pneumonia. Chin Med J 125: 894-900.

Warren RE, Ensor VM, O’Neill P, Butler V, Taylor J, Nye K, Harvey M, Livermore DM, Woodford N, Hawkey PM 2008. Imported chicken meat as a potential source of quinolone-resistant Escherichia coli producing extended-spectrum beta-lactamases in the UK. J Antimicrob Chemother 61: 504-508.

Xu X, Cui S, Zhang F, Luo Y, Gu Y, Yang B, Li F, Chen Q, Zhou G, Wang Y, Pang L, Lin L 2014. Prevalence and characterization of cefotaxime and ciprofloxacin co-resistant Escherichia coli isolates in retail chicken carcasses and ground pork, China. Microb Drug Resist 20: 73-81. 